\title{
Transformation of the State Judicial System through E-Court System in Banda Aceh State Administrative Court
}

\author{
Arif Rahman, Elidar Sari, ${ }^{*}$ Hadi Iskandar \\ Law Faculty, University of Malikussaleh Indonesia \\ * E-mail of the corresponding author: elidarsari@unimal.ac.id
}

\begin{abstract}
State Administrative Courts have existed since 1991, public and state trust in this court is getting bigger and bigger. This requires the judiciary to be able to balance its functions and technology in accordance with these developments. So that electronic justice is very much needed at this time, and of course it must be supported by rules and implementing guidelines that are in accordance with the law. E-Court is sometimes considered a necessity as is the case with e-Commerce, especially the complex cases contained in the essential values of justice, the world of justice must also ask for electronic assistance for the smooth running of the judiciary. As will see the authenticity Beschikking needed electronics. So, it is necessary to know the readiness of the Banda Aceh State Administrative Court in dealing with all of this. As a sample location for this study. There are several things that are the focus of this research, namely the use of technology in the justice system towards a Simple, Efficient and Affordable online court system (e Court), forms of judicial transparency, and how the electronic justice process is in accordance with applicable legal rules.
\end{abstract}

Keywords: Judiciary, Electronic, e-Court online trial

DOI: $10.7176 / \mathrm{JLPG} / 118-09$

Publication date: February $28^{\text {th }} 2022$

\section{Introduction}

The implementation of spatial arrangements in Indonesia aims to realize a safe, comfortable, productive and sustainable region based on archipelago insight and national resilience. This goal can be achieved through efforts to realize coherence in the use of artificial resources by paying attention to existing human resources so that the realization of space functions and prevention of negative impacts on the environment due to the use of space.

Constitutionally Article 33 paragraph (3) of the Constitution of the Republic of Indonesia 1945 states "the earth and natural wealth contained therein are controlled by the state and used as much as possible for the prosperity of the people". The provision is the basis for the birth of further legislation arrangements, among others concerning spatial planning. That the existence of limited space and the understanding of the community that develops on the importance of spatial arrangement so that it is necessary to organize a transparent, effective and participatory space to realize a safe, comfortable, productive, and sustainable space. ${ }^{1}$

This is in accordance with the consideration of the Law of the Republic of Indonesia Number 26 of 2007 , that the Law of the Republic of Indonesia Number 24 of 1992 concerning Spatial Arrangement is not in accordance with the needs of spatial arrangement arrangements so it needs to be replaced with the new Spatial Arrangement Law. ${ }^{2}$

In connection with this to realize the general welfare for all Indonesian people, the government is obliged to realize public facilities and infrastructure that can improve the quality of people's lives while supporting the national economy. Infrastructure development is one of the important elements in public sector investment needed to support the achievement of one of these national goals.

Article 11 of spatial arrangement law No. 26 of 2007 states that "the district/city government has authority in the implementation of spatial arrangements that include the arrangement, construction and supervision of the implementation of district/city spatial arrangements". According to the Law of the Republic of Indonesia No. 23 of 2014 on Local Government is determined "Regions are given the power to manage and utilize the potential resources they have".

Thus, the North Aceh Regency Government of Indonesia has the authority to manage, extract and utilize natural resources for the implementation of welfare by referring to the provisions or principles of good and integrated and open urban spatial planning. Realizing this, of course, is not as easy as many people think.

The success of spatial arrangement of an area is also inseparable from the good role of the government and its supporting agencies, spatial planning must in principle be by Article 33 paragraph (3) of the 1945 Constitution. This provision is a logical consequence of the State of the Republic of Indonesia which adheres to democracy.

\footnotetext{
${ }^{1}$ The consideration of letter (d) of the Law of the Republic of Indonesia Number 26 of 2007 concerning Spatial Arrangement.

${ }^{2} \operatorname{Ibid}(\mathrm{f})$
} 
According to Hestu Cipto Handoyono with the control of the earth and the natural wealth contained in it by the state, then the equalization of these management results will be achieved, another case if controlled by individuals in (private). ${ }^{1}$ There is a very close relationship between the community and spatial planning as a container of city activities where the center of community activities is always developing both quality and quantity by the growth and development of development with the form of space structures and patterns of space that are good for the people of the city and the surrounding area. In general, it is known that behind the results of the physical development of the city that supports the welfare of the community, not a few development impacts are felt to harm the life (physical and psychological) of the community. The rapid development of urban areas, in addition to having a positive impact on economic development, turns out that on the other hand it can cause environmental problems. ${ }^{2}$

In general, spatial plans have not been fully used as a reference in the implementation of development and the weak aspects of supervision and supervision and the absence of sanctions for violators. Increasing public awareness and the growing demands for the application of the principles of good governance becomes a matter of consideration as well. In addition, in society, there are also often conflicts caused by reasons of inequality of ownership, mastery, and management of agrarian sources, or so-called inequality of agrarian structures. All of which has encouraged the need for more firm and comprehensive arrangements on aspects of rights, obligations, and the role of the community more transparently and law enforcement in the implementation of spatial arrangements becomes very important.

To respond to the phenomenon in the three districts/cities again try to adjust the existing draft qanun with the Law of the Republic of Indonesia Number 26 of 2007 by involving the services of consultants and parties deemed necessary. The qanun design that has been produced is considered to have the value of planning the utilization and control of maximum spatial utilization based on the principle of good spatial arrangement.

One of the principles in a spatial arrangement is openness as stipulated in Article 2 letter (e) of the Law of the Republic of Indonesia Number 26 of 2007. The principle of openness is attached to the principle of democracy in the implementation of government which shows that the principle of democracy is not only carried out through the representative body of the people, but also by every citizen in connection with the government's actions in the form of decisions. ${ }^{3}$

The spatial arrangement, especially the spatial planning process is included in the administrative aspects that at the legal level of implementation of the principle of openness must be fulfilled and implemented. The spatial arrangement of the North Aceh Regency Government has been carried out based on policy so that the development carried out is less integrated and even less touching on the values of spatial beauty and community desires. This is because no qanun that gives specific instructions and understanding.

The qanun plan that has been made certainly cannot bind perfectly to the policies pursued by the city government in realizing good spatial planning, what's more, the qanun plan still needs to be tested for truth usefulness, and certainty in the discussion of the local legislature. One aspect that still needs to be known and discussed further is the rights, and obligations and forms and procedures of the role of society in spatial arrangement. Currently North Aceh has completed the establishment of Qanun Spatial Qanun North Aceh No. 7 of 2013 concerning The Spatial Arrangement of North Aceh.

This needs to be done considering that one of the purposes of spatial arrangement is intended to provide comfort to live in a good quality environment for the people of the city and surrounding areas, thus the principle of openness really needs to be strengthened in the process of preparing spatial planning. Technical how the process of networking people's aspirations must certainly be done more transparently. The public has the right to know openly the regional spatial plan, the regional spatial plan, the detailed spatial plan of the area. ${ }^{4}$

Because the application of the principle in spatial planning is important, it is urgent or necessary to research whether the principle of openness has been applied in the development of spatial planning in the three districts of the city. Based on the background above, the formulation of the problem in this study is How Effective is the Application of Openness in Spatial Arrangement in North Aceh Indonesia.

\section{B. RESEARCH METHOD}

The research of this article follows a normative approach in analyzing the application of e-court in the SAC of Banda Aceh and its impact on judicial processes and access to justice. Primary and secondary data were obtained

\footnotetext{
${ }^{1}$ Hestu Cipto Handoyono, Apek-Aspek Hukum Administrasi Negara Dalam Penataan Ruang (Yokyakarta: Admajaya, 2001).

2 Muhar Junef, "Penegakan Hukum Dalam Rangka Penataan Ruang Guna Mewujudkan Pembangunan Berkelanjutan," Jurnal Penelitian Hukum De Jure 17, no. 4 (2017).

${ }^{3}$ Philipus M. Hadjon, Hukum Administrasi Negara Raja Grafindo Persada, 2006.

${ }^{4}$ Article (2) of Government Regulation of the Republic of Indonesia Number 69 of 1996.
} 
from interviews, literature studies and tracing various official reports of the Supreme Court, journals and other supporting literature for further analysis and descriptive presentation.

\section{DISCUSSION}

The issue of justice has long been a subject of study among religious philosophers, politicians, thinkers and jurists. Justice is the basic ideal of independence for every nation. In essence, justice has long been a problem in human life because it is one of the main necessities of human life. Since the beginnings of Greek philosophy, the theme of justice has been a central theme. Discussions about justice have broad dimensions, ranging from ethical, philosophical, legal, to social justice.

"Ubi Societas, Ibi Ius", was conveyed by Cicero, a Greek philosopher (Tărchilă, 2015). This means that where there is a community there is a law. From this situation it can be analogized as follows that where there is a community there is a violation of the law. This law violation problem does not consider who the perpetrators are and where the perpetrators come from. It could be that the violations came from rural, urban, rich or poor communities. So, this violation does not look at the social status of a certain person, and can happen anywhere and anytime. This is where the judicial function is needed to take action against the perpetrators of these violations of the law. In addition, the judiciary is also expected to follow the development of society, and the legal system can follow the development of society. In accordance with Paul Scholten's opinion, the legal system is an open system, where it will not be finished and it is impossible to finish because it will continue to be able to add new things to the system to keep up with the development of society (Manullang, 2019).

The concept of access to justice focuses on two basic objectives of a legal system, namely: 1) the legal system must be accessible to all people from all walks of life; and 2) the legal system must be able to produce laws and decisions that interpret and apply fair law to all parties, both individually and in groups. The priority of this conceptualization is measured to achieve social justice for citizens from all walks of life (Ministry of National Development Planning RI, 2016).

\section{Transformation of the Indonesian Justice System to a Simple, Efficient and Affordable e-Court System.}

Reform of procedural law is urgently needed in relation to current developments which require law enforcers, especially judges, to be ready to keep up with technological developments. It is also hoped that the SAC judicial procedural law will be able to follow this development well and the procedural law rules can also adjust. Important issues in dealing with electronic justice in the SAC environment are how to use technology to lead to simple, fast and low-cost justice. In response to this, it is necessary to prepare an electronic court at the first instance of case examination, appeal and even to appeal.

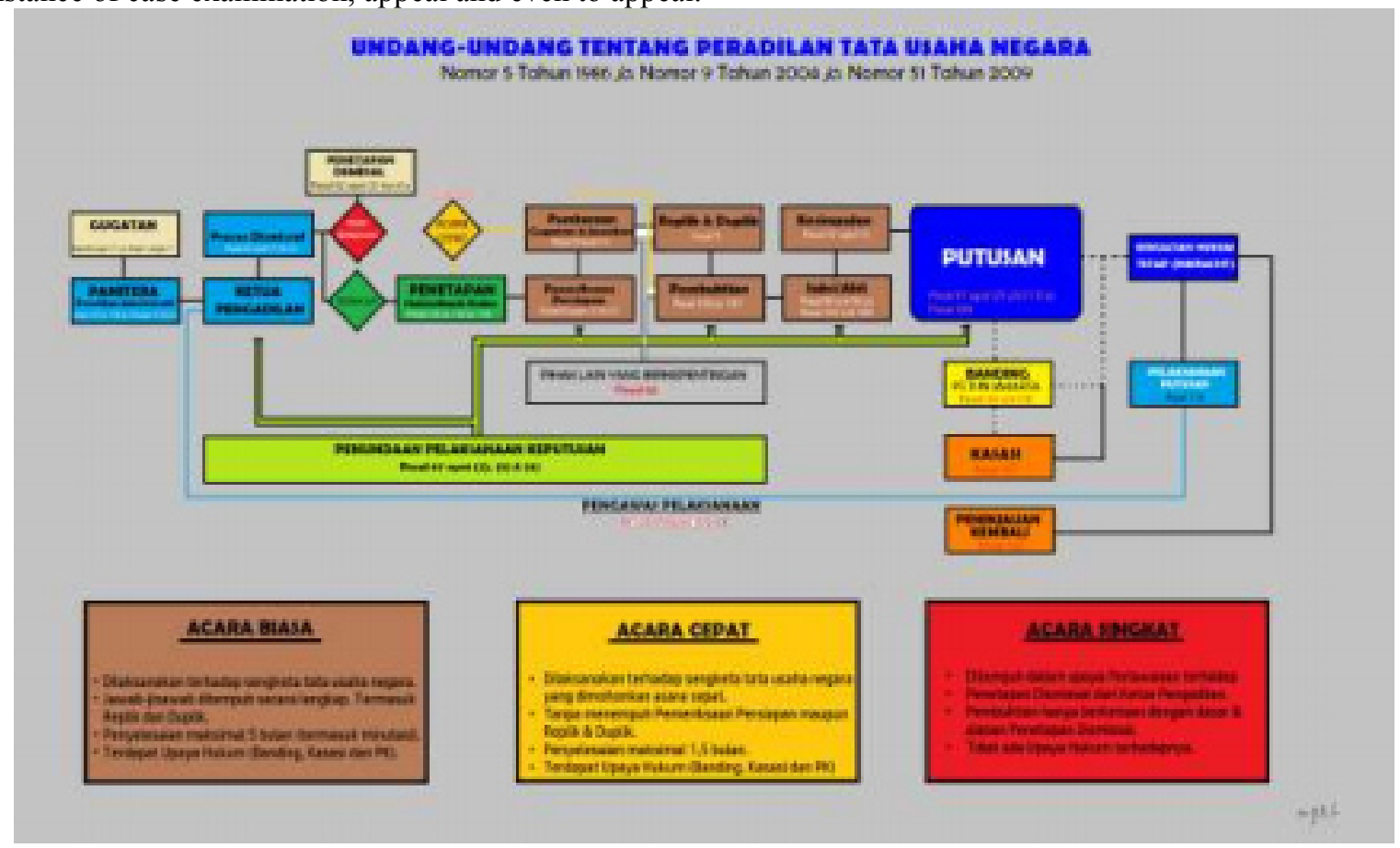

Figure 1. The State Administrative Court Dispute Process

Based on Law Number 5 Year 1986 jo. Law Number 9 of 2004 jo. Law Number 51 of 2009 concerning the process of dispute proceedings in SAC through 3 types of events, namely Ordinary Events, Fast Events and Short Events. This aims to sort out the types of cases and also to consider the urgent interests of the disputing 
parties in the SAC. Furthermore, with the issuance of the Court Regulation Number 1 of 2019, the judicial process procedures which should be carried out conventionally through the registration system and judicial administration at the SAC, efforts are made to carry out the registration and administration process through an electronic system that can assist and facilitate using information technology assistance.

The online trial process (e-Court) is believed to be able to realize the principles of a simple, fast and lowcost trial. The judicial process will be brief and straightforward, which can be seen from the comparison of conventional and digital case registration processes. The parties in a case no longer have to take care of their registration interests by visiting the service room at the SAC office. The availability of electronic devices and supporting applications has eliminated time and space limitations, so that wherever the litigants are located, they can continue to follow or continue the trial process, without having to come directly to the courtroom. In terms of court costs, the cost of electronic calls is estimated to be lower than conventional calling costs using registered mail. ${ }^{1}$

Information technology governance arrangements at SAC of Banda Aceh have changed the process of administering and registering cases through the e-Court System. This system has also been integrated with the $e$ Filling, e-Payment, e-Summons, and e-Litigation features. This e-Court system has also been integrated with the Case Tracking Information System (SIPP), so that the process of recording case administration from the start to the decision stage of the case is all electronically recorded and reduces the double registration aspect of several different applications (Supreme Court of the Republic of Indonesia, 2019a).

The e-Court system aims to streamline court functions, including case administration, case administration records, summons of parties, provision of copies of court decisions, administrative governance, and payment of court fees. All of these functions are carried out electronically / online when filing state administrative lawsuits without the need to come to the courthouse.

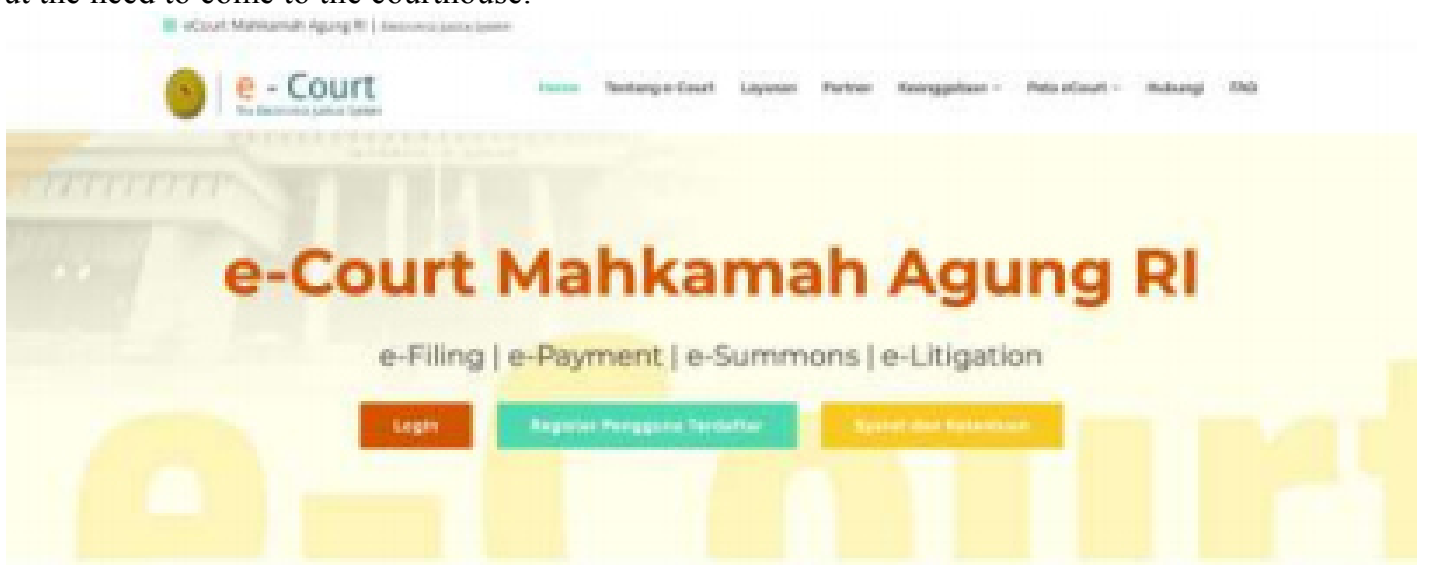

Figure 2. MA-RI e-Court Service Application

The payment process related to cases is also expected to be more convenient because the electronic payment system allows payments to be made from any bank with any electronic payment channel, such as internet banking, SMS banking, and ATM transfers through relevant court partners. It is hoped that this electronic payment system will directly reduce the practice of extortion in court cases, of course it has burdened the public when proceeding in court, especially those with low income.

Electronic dial (e-Summons) can also simplify processes and reduce costs, by allowing direct services or processes to electronic domicile, also eliminating the need for delegation procedures if the parties are in different jurisdictions. This allows costs to be kept to a minimum. The 2018 MA Annual Report states that in 2018, 907 cases had been submitted to the e-court with details of 445 cases registered using e-court in general courts, 422 cases in religious courts, and 20 cases in State Administrative Courts (Santiadi, 2019).

Registered users on the e-Court system are currently still limited to advocates, while other registered users from individuals and legal entities will be further regulated, according to the provisions in Article 5 paragraph (3) Court Regulation Number 1 of 2019 (Supreme Court of the Republic of Indonesia, 2018). Currently, the Supreme Court of the Republic of Indonesia has appointed as a pilot project for this e-Court system, especially in the State Administrative Court, as many as 30 SACs throughout Indonesia. SAC of Banda Aceh, which is the location and object of this article's research, is also one of the pilot projects. Based on the data obtained, at this time SAC of Banda Aceh has successfully served registration of state administration cases online with the data as listed in the following table: (Supreme Court of the Republic of Indonesia, 2019b)

\footnotetext{
${ }^{1}$ Interview, Yusri Arbi, Chairman of PTUN Banda Aceh, 11 November 2020
} 
Table 1 Number of Online TUN Case Registration

\begin{tabular}{|c|c|c|}
\hline No. & Activity & $\begin{array}{c}\text { Number of } \\
\text { Cases }\end{array}$ \\
\hline 1 & Registration (Paid) & 66 \\
\hline 2 & Successful Case Number & 66 \\
\hline 3 & Lawsuit Case & 63 \\
\hline 4 & Request & 3 \\
\hline
\end{tabular}

The table shows that the tools and applications of the SAC of Banda Aceh e-court in handling the administration of online case registration are ready to be used in online services. However, there are still obstacles in implementing online case registration. This was found from the existence of litigants who wanted to register online, but they still lacked knowledge in operationalizing the e-Court application. There needs to be a wider outreach effort from the SAC of Banda Aceh to the public using the state administration court, so that these electronic services can be more easily used by the litigants.

Technical instructions from Regulation Number 1 of 2019 concerning the Implementation of Cases and Trials at Electronic Courts and e-litigation applications have also been issued through the Decree of the Chief Justice of the Supreme Court Number 129/ KMA/VIII/2019 concerning about the Case Technical Guidelines. Electronic Administration and Testing. This shows that not only can the administrative process for trial registration be carried out online, but also at the stage of examination of witnesses, experts and trial evidence. This examination can be carried out using video tele-conference media, where witnesses or experts and evidence can be presented to the court through video equipment that has sufficient quality, so that the evidence displayed will appear as if the judge will see the evidence directly if carried out the trial conventionally.

The above is also still an obstacle encountered in the process of conducting online trials, so it is necessary to pay attention to the SAC of Banda Aceh to be able to improve the quality of video tele-conference equipment as well as standard operating procedures for examining evidence and expert witnesses through video teleconference. so that the SAC judge can be absolutely sure in examining this matter online.

2. The Impact of Changes in the Modern Justice System in the Procedure System and Access to Justice in the Judiciary.

In line with the development of information technology, the transformation of the court into a modern court that utilizes digital information technology to its full potential is a necessity. Reiling (2010) who examined the impact of information technology on judicial administration, states that court clients around the world complain mainly about long delays, lack of access to justice and court corruption. Thus, the use of technology for justice is basically in line with the principle of informed dispute resolution. As in court, alternative dispute resolution is subject to the principles of speedy and timely, low cost and simpler method.

The application of case administration in court electronically in accordance with the Regulation Number 1 of 2019 is also in line with the General Principles of Good Judiciary. The principle of justice that is open to the public, where with the application of case administration electronically, these documents can not only be accessed by the parties who are involved, but the general public can access and control them.

Public demands for justice services are increasing, in line with the increasing access and use of information technology and various regulations that open up space for the public to access information and get excellent service from public institutions. With these conditions, the judicial apparatus must increasingly open up to change and adapt to the current developments in the world of information technology. ${ }^{1}$ It is also hoped that the transparency of the system applied to the courts can gradually reduce the practice of extortion in courts that was usually done before. As it is known, the practice of extortion has a significant impact on access to justice for the community. This corruption practice arised because of the increasing costs that must be incurred by justice seekers in court services due to a long and winding administrative process that involves many parties. This practice previously gave birth to brokerage practices and other procedural irregularities (Santiadi, 2019).

The direct impact of implementing the temporary e-court can be seen from the results of a public satisfaction survey conducted by the Department of Research, Education, Economic and Social Information and the Supervisory Body of the Supreme Court on court institutions in 60 work units of court institutions (State Administrative Courts, Courts General and Religious Courts) in 20 Provinces in Indonesia. The results of the surveys conducted on January 21 to February 152019 showed that the overall index of public satisfaction with court institutions was $76 \%$ in the good category. The results of the current public satisfaction study have

\footnotetext{
${ }^{1}$ Interviews, Yusri Abdi, Chairperson of PTUN Banda Aceh
} 
increased by $6.7 \%$ points in a period of five years (2014 - 2018) (Santiadi, 2019).

Through the application of e-court, it is hoped that the public's trust and access to court institutions and law enforcement officials, especially in courts, will continue to increase. This is in line with what Stephan Golub stated, that a very important element in access to justice is that the existence of a formal legal institution should be trusted by the community as an efficient, neutral and professional institution. According to Golub (2003) public satisfaction and trust in formal institutions is very important. Thus, the presence of e-court is part of the court's efforts to provide easy access to the public and justice seekers in addition to efforts to make the courts more transparent, effective and efficient.

\section{CONCLUSION}

Based on the above explanation, the following conclusions can be concluded:

1. That the transformation of the Indonesian Justice System to a Simple, Efficient and Affordable e-Court System can be carried out with an online justice system and is very easy to use, especially in the current conditions. is currently in a pandemic. It's just that not all people are capable and able to operate it, with various obstacles such as understanding knowledge, uneven internet networks, incomplete facilities and infrastructure and not yet familiar with all existing technologies.

2. Whereas the impact of changes in the modern system of justice in the judicial system and access to justice in the judiciary, especially the state administrative court, is getting better, because the process of utilizing technology is more transparent and the public is free to access, this is evidenced by the results of the public satisfaction index for court institutions of $76 \%$ are in the good category. The results of the current public satisfaction study have increased by $6.7 \%$ points in a period of five years, from 2014 to 2018 . Through the application of e-court, it is hoped that public trust and access to court institutions and law enforcement officials, especially in state administrative courts, will continue to increase.

\section{BIBLIOGRAPHY}

Golub, S. (2003). Beyond Rule of Law Orthodoxy: The Legal Empowerment Alternative. In Rule of Law Series: Democracy and Rule of Law Project.

Ministry of National Development Planning / Bappenas RI. (2016). National Access to Justice Strategy 20162019. In the National Access to Justice Strategy 2016-2019. Retrieved from https://www.undp.org/content/dam/indonesia/2016/press doc / SNAK book rev (2) -4-5-16.pdf

Supreme Court of the Republic of Indonesia. (2018). Supreme Court 2018 Annual Report; A New Era of Information Technology-Based Modern from https://mahkamahagung.go.id/files/20190219121709 FA MA 20119- interactive.pdf

Supreme Court of the Republic of Indonesia. (2019a). e-Court of the Supreme Court of the Republic of Indonesia.

Supreme Court of the Republic of Indonesia. (2019b). Map of the e-Court of the Supreme Court of the Republic of Indonesia.

Manullang, FM (2019). FEEDBACK OF LEGAL SCIENCE STRUCTURE ACCORDING TO PAUL SCHOLTEN. Journal of Law \& Development.

https://doi.org/10.21143/jhp.vol49.no1.1909

Reiling, D. (2010). Technology for Justice: How Information Technology can support Judicial Reform. In Technology for Justice: How Information Technology can support Judicial Reform. https://doi.org/10.5117/9789087280710

Santiadi, K. (2019). EXPANDING ACCESS TO JUSTICE THROUGH E-COURT IN INDONESIA. Prophetic Law Review. https://doi.org/10.20885/plr.vol1.iss1.art5

Schmitz, AJ (2019). Expanding access to remedies through e-court initiatives. Buffalo Law Review.

Setiawan, W. (2017). The Digital Age and its Challenges. National Education Seminar.

Tărchilă, P. (2015). HISTORICAL EVOLUTION OF THE LAW. Agora International Journal of Juridical Sciences. https://doi.org/10.15837/aijjs.v9i3.2114

Voermans, W. (2007). Judicial Transparency Furthering Public Accountability for New Judiciaries. Utrecht Law Review, 3(1), 148-159.

https://doi.org/https://doi.org/10.18352/ulr.42

Yogyakarta, P. (2019). E-court and the Future of the Modern Justice System in Indonesia. Retrieved November 18, 2020, from PTUN Yogyakarta website: https: // ptun yogyakarta.go.id/index.php/artikel/193-e-courtdan-masa-depan-sistem-modern justice-in-indonesia.html 